\title{
Excellent Measures Precede Measures Of Excellence
}

\author{
Hamish Coates $^{i}$ \\ Australian Council for Educational Research (ACER), Private Bag 55, Camberwell, Victoria, 3124, \\ Australia
}

This paper identifies quantifiable indicators that might enhance the national evaluation of learning and teaching in Australian higher education. It begins by setting out a framework suitable for guiding the identification and selection of indicators. After a brief critical review of current indicator possibilities, it defines a number of possible indicators that might be developed. The paper works from the premise that as greater significance is placed on the outcomes of measurement, we need to place greater significance on measurement itself. It is imperative that appropriate and contemporary analytical methods are used, and that evaluations are developed in ways that ensure that the basic availability of data does not dictate the approach.

\section{Selecting Indicators to Frame National Evaluations}

This paper presents a broad but targeted analysis of the quantifiable indicators required to enhance the national evaluation of learning and teaching in Australian higher education. It offers a pragmatic, educationally-sensitive and methodologically-informed perspective on this important part of higher education. The national evaluation of university education is growing, underpinning a need to develop valid, reliable and fair indicators of educational activities and outcomes.

Monitoring higher education teaching and learning at the national level is an innovative endeavour. Academic pedagogy and learning can be difficult to define, measure, analyse, review and report in ways that are generalisable across fields of study, let alone across institutions, states or nations. Developing standard measures that are valid across diverse institutions and contexts is a challenging task. Nevertheless, Australia is a leader in this area, and has the capacity and policy imperatives to further develop methodologies that may also assist other countries around the world.

Despite its critics and inherent difficulties, it seems very likely that such large-scale evaluation of university education is here to stay. Indeed, a wave of recent developments suggest that this is a fast growing area of higher education. While not focused exclusively on university learning and teaching, recent institutional ranking exercises have helped popularise comparative reports of institutional performance (Usher \& Savino, 2006; Williams \& Van Dyke, 2005; THES, 2004; IEH, 2004). In Canada, an innovative attempt has just begun to develop a 'composite learning index' to represent the current state of learning across the country (Cartwright, Mussio \& Boughton, 2006). In Australia, much discussion has been stimulated during development of the Learning and Teaching Performance Fund (LTPF) (Nelson, 2003).

As greater significance is placed on the outcomes of measurement, we need to place greater significance on measurement itself. While certain aspects of large-scale evaluation are relatively new to higher education, methods used to measure and monitor educational effectiveness have been widely used and rigorously tested over many years, in schools in particular. It is imperative that appropriate and contemporary analytical methods are used, to maximise the validity, reliability and fairness of large-scale measures of university education.

\footnotetext{
${ }^{\text {i }}$ I am very grateful for value feedback provided by Dr Phillip McKenzie, Dr John Ainley and Dr Ken Rowe on earlier versions of this paper.
} 
The following analysis focuses on identifying which phenomena might be assessed in large-scale evaluations of university education. It does not examine the rationale for such evaluations, nor the important issues of analysis or reporting. Developing overall confidence in such evaluations begins with developing confidence in the authority and validity of the performance indicators on which evaluations, rankings and funding decisions are made. Such evaluations are almost invariably high-stakes, and it is critical that performance indicators are valid and appropriate.

\section{Criteria for Selecting Indicators}

Developing indicators to measure complex educational phenomena is itself a complex task. Much research has been done in this area (Cuenin, 1988; Kells, 1993; Cave, Hanney, Henkel \& Kogan, 1997; Johnes \& Taylor, 1991; McDaniel, 1996; Linke, 1991), and much is now known about developing reliable and useful indicators for higher education. Key properties are summarised by Krause, Coates and James (2005).

Performance indicators are most powerful when they are situated in a framework. The hierarchical inputprocess-output framework is one of the most general. This basic but robust framework has been used across a large number of diverse education systems and contexts (Bottani \& Tuijnman, 1994; Astin, 1985; Ewell \& Jones, 1996; Jaeger, 1978; Nuttall, 1994). Many different indicators can be located in this framework. Indicators are included because of their perceived relevance, because they are ready-to-hand, or for political or educational rationales. Table 1 presents this basic framework, and includes examples of common indicators. For parsimony, context factors have been excluded, as these typically represent phenomena beyond an institution's control.

Table 1: Performance Indicator Framework with Examples

\begin{tabular}{llll}
\hline \multirow{3}{*}{ Institutions } & \multicolumn{1}{c}{ Inputs } & \multicolumn{1}{c}{ Processes } & \multicolumn{1}{c}{ Outcomes } \\
\cline { 2 - 4 } & $\begin{array}{l}\text { Capital resources } \\
\text { Institutional reputation }\end{array}$ & $\begin{array}{l}\text { Institutional contexts } \\
\text { Learning systems }\end{array}$ & $\begin{array}{l}\text { Growth } \\
\text { Reputation }\end{array}$ \\
\hline Staff & Teaching qualifications & Teaching processes & $\begin{array}{l}\text { Teaching experience } \\
\text { Teaching resources }\end{array}$ \\
& Teaching experience & & \\
& Teaching staff numbers & & \\
& Expenditure per student & & Course completions \\
& Staff/student ratios & & Graduate and generic \\
Students & Entry scores & Engagement processes \\
& Student diversity & Retention and attrition & Engagement outcomes \\
& Demand/selectivity & & Learning outcomes \\
& Study access/equity & & Graduate destinations \\
\hline
\end{tabular}

\section{A Brief Critique of Current Indicator Possibilities}

Development of the Learning and Teaching Performance Fund (LTPF) (Nelson, 2003) provided an opportunity for a national critique of indicators of learning and teaching in Australian higher education. An early discussion paper suggested a range of indicators and evaluation methods that might play a role in a LTPF allocation model (DEST, 2004). From this starting point, a series of reviews, consultations, analyses and decisions were made to produce the allocation model used for the initial distribution in 2006 (AVCC, 2004; Access Economics, 2005; DEST, 2005).

Table 2 summarises the indicators and their weighting in the initial allocation model. The Course Experience Questionnaire (CEQ) (Ramsden, 1991) Good Teaching Scale (GTS), Generic Skills Scale (GSS) and Overall Satisfaction Item (OSI) are administered as part of a census of Australian university graduates a few months after graduation. The Graduate Destination Survey (GDS) work and study statistics are collected in the same census. Measures of first year attrition and progress are generated from annual data collected from institutions. 
Table 2: Initial LTPF Allocation Model

\begin{tabular}{lccc}
\hline \multirow{2}{*}{ Institutions } & Inputs & Processes & Outcomes \\
\cline { 2 - 4 } Teachers & - & - & - \\
& - & CEQ GTS (18.52\%) & - \\
& & CEQ GSS (17.91\%) & \\
\hline Students & & CEQ OSI (18.90\%) & \\
& - & ATTRITION (10.65\%) & GDS WORK (11.48\%) \\
& & PROGRESS (12.26\%) & GDS STUDY (10.29\%) \\
\hline
\end{tabular}

A few brief reflections on current possibilities provide a foundation for the analysis that follows. Table 2 shows that the available data is limited and is focused on only a few aspects of university education. There is no data on input factors, institution-level indicators, and only restricted behavioural measures of learning processes and outcomes.

As elaborated by Coates (2005), the two measures of learning processes are very basic in nature. Measures of student progress may reflect low course standards rather than high quality student performance, and are only binary measures. While student attrition is a number that can be used, attrition is a complex concept that has many varied connotations. Low progress and high attrition may indicate constructive mobility as much as stagnation or lacking persistence.

A system of indicators should include those which provide leading, coincident, and lagging information. Typically, although not essentially, input indicators provide leading information, process indicators provide coincident data, and outcome measures provide lagging data. A major limitation of the indicators in Table 2 is that they all provide lagging information of, in many cases, performance two years earlier. Lagging information can be difficult to attribute in precise or accurate ways to detailed institutional and educational processes. Attribution difficulties aside, in a fast moving sector it is very possible that major changes or restructures may reduce the relevance of the lagging data.

It is clear that at present national indicators on teaching and learning in higher education are too reliant on a single source of data. Just under 80 per cent of all data is derived from a single graduate census. This census was not developed as a funding mechanism, and is administered in a decentralised and diverse fashion by the institutions themselves. Concentration on this single source introduces a lack of variability into the data, prevents the kinds of triangulation and verification that a more diverse selection of indicators would provide, and focuses attention on a small range of phenomena.

Ideally, indicators should reflect the extent to which institutions and teachers have developed the talent of individual students (Astin, 1985). Measures of the value added by education expose the net effect of education contexts and processes. This does not yet appear possible in the data currently available for national evaluation of university education in Australia. Students are admitted into courses based on an increasingly diversified series of selection mechanisms, and there are no commonly accepted measures of their learning outcomes at the end of their university studies.

\section{Indicators and Developments that Might be Considered}

There is a need for review and enhancement of the performance indicator framework developed by Linke (1991) around 15 years ago. Sector size, structure and dynamics have changed considerably since this framework was developed. It is important that the framework develops to keep pace with such significant developments as the growth in international education, new data management technologies, advances in educational measurement, and contemporary conceptions of educational quality. The framework needs to grow to encompass new and much needed statistics. At the same time, new measures and approaches have been developed outside the framework, such as the new CEQ scales (McInnis, Griffin, James \& Coates, 2001), the First Year Experience Questionnaire (FYEQ) (Krause, Hartley, James \& McInnis, 2005), and a student equity framework (James, Baldwin, Coates, Krause \& McInnis, 2003). Such indicators should be underpinned by the framework to enhance their authority, and the authority of the framework itself.

Australia needs a robust measure of 'student engagement'. Student engagement is concerned with the point of intersection between individuals and the things that are known to be critical for their learning 
(Coates, 2006). The idea is intended to provide a singularly sufficient means of capturing the broad range of educationally significant interactions that learners have with their study, teachers and institutions. Managing these interactions helps institutions engage students with the resources and experiences that help them learn.

There is a pressing need to develop sounds measures of academic learning outcomes. In principle, such measures would provide a direct and efficient means of measuring the quality of learning in Australian higher education. Unfortunately, outcomes from academic learning can be difficult to specify, measure, generalise and interpret. Also, and partly due to these difficulties, Australian higher education lacks generalisable, reliable, validated and criterion-referenced measures of learning outcomes. In individual subjects, student knowledge and skill is often measured using uncalibrated tasks with unknown reliability and validity, scored normatively by different raters using unstandardised rubrics then, often with little moderation, adjusted to fit percentile distributions which are often specified a priori by departments, faculties or institutions. Questions about the quality of learning should be informed by more comprehensive and robust forms of assessment.

Even with existing measures of learning outcomes, however, the calculation of a grade point average for each student would provide a direct and nationally generalisable measure of learning outcomes. Grade point averages have been used in Australia for many years to select people into graduate medical programs (ACER, 2006). The methods used to calculate these averages could be expanded and further validated. To ensure comparability across institutions, for instance, it might be prudent to collect robust national data which could be used to calibrate and validate estimates of performance.

An assessment of generic skills has the capacity to directly measure important general outcomes of university education. If administered in appropriate ways, it also has the capacity to produce generalisable measures of the net educational effects of university study. The Graduate Skills Assessment (GSA) (ACER, 2001) has been designed to play this role in the sector, but uptake within the sector has been very low. Further work could be undertaken to develop infrastructure and processes for routine administration.

A measure of graduate skills obtained from a survey of large graduate employers would provide an independent and alternative perspective on the quality of Australian university education. Such surveys have been undertaken on a small scale, there would be a need for development of a large-scale instrument and methodology. In addition to its possible role in the LTPF, such a survey would provide useful information for employers, institutions and potential students.

\section{Advancing National Evaluations of Learning and Teaching}

Through a normative analysis of currently available indicators, the above analysis has defined possibilities for indicators which might enhance national evaluations of the quality of learning and teaching in Australian higher education. Developing such indicators is necessarily a complex and challenging task, not least because it needs to account for practical, methodological and educational considerations.

It is important, however, that national evaluations of learning and teaching are developed in ways that ensure that the basic availability of data does not dictate the approach. If a data-driven policy approach is desired, it is critical that valid data is developed and used. Performance indicators shape quality considerations in many ways, and it is important to ensure that they are salient, sufficient and sound. An important part of enhancing the quality of teaching and learning is enhancing the measures on which quality judgements are made.

\section{References}

Access Economics. (2005). Review of Higher Education Outcome Performance Indicators. Canberra: Access Economics.

Astin, A. W. (1985). Achieving Educational Excellence: A critical analysis of priorities and practices in higher education. San Francisco: Jossey Bass. 
Australian Council for Educational Research (ACER) (2001). Graduate Skills Assessment. Canberra: Department of Education, Training and Youth Affairs.

Australian Council for Educational Research (ACER) (2006). Graduate Australian Medical Schools Admission Guide 2005. Camberwell: ACER

Australian Vice Chancellors' Committee (AVCC). (2004). Performance Indicators for Teaching and Learning. Canberra: AVCC.

Bottani, N., \& Tuijnman, A. (1994). International Education Indicators: Framework, development and interpretation. In A. Tuijnman \& N. Bottani (Eds.), Making Education Count: Developing and using international indicators. Paris: OECD.

Cartwright, F., Mussio, J. \& Boughton, C. (2006). Developing a Composite Learning Index: A framework. Ottawa: Canadian Council on Learning

Cave, M., Hanney, S., Henkel, M., \& Kogan, M. (1997). The Use of Performance Indicators in Higher Education: The challenge of the quality movement. London: Jessica Kingsley Publishers.

Coates, H. (2005). The value of student engagement for higher education quality assurance. Quality in Higher Education, 11(1), 25-36.

Coates, H. (2006). Student Engagement in Campus-based and Online Education: University connections. London: Routledge.

Cuenin, S. (1993). Performance indicators in higher education: A study of their development and use in 15 OECD countries. In: Kells, H. (Ed.) The Development of Performance Indicators in Higher Education: A compendium of twelve countries. Paris: OECD.

Department of Education Science and Training (DEST). (2004). Learning And Teaching Performance Fund: Issues paper. Canberra: DEST.

Department of Education Science and Training (DEST). (2005). Learning and Teaching Performance Fund: Discussion paper. Canberra: DEST.

Ewell, P. T., \& Jones, D. P. (1996). Indicators of "Good Practice” in Undergraduate Education: A handbook for development and implementation. Colorado: National Centre for Higher Education Management Systems.

Institute of Higher Education (IHE) (2004). Academic Ranking of World Universities - 2004. Shanghai: IHE, Shanghai Jiao Tong University.

Jaeger, R.M. (1978). About educational indicators: Statistics on the conditions and trends in education. Review of Research in Education, 6, 276-315.

James, R. H., Baldwin, G., Coates, H. B., Krause, K., \& McInnis, C. (2003). Analysis of Equity Groups in Higher Education 1991-2002: Preliminary Report. Canberra: Department of Education, Science and Training.

Johnes, J. \& Taylor, J. (1991) Performance Indicators in Higher Education: UK universities. Buckingham: Society for Research into Higher Education and Open University Press.

Kells, H. (Ed.) (1993). The Development of Performance Indicators in Higher Education: A compendium of twelve countries. Paris: OECD.

Krause, K., Coates, H., \& James, R. (2005). Monitoring the internationalisation of higher education: Are there useful quantitative performance indicators? In M. Tight (Ed.), International Perspectives on Higher Education Research. London: Elsevier Limited. 
Krause, K., Hartley, R., James, R., \& McInnis, C. (2005). The First Year Experience In Australian Universities: Findings from a decade of national studies. Canberra: Department of Education, Science and Training.

Linke, R. D. (1991). Report of the Research Group on Performance Indicators in Higher Education. Canberra: Department of Education, Training and Youth Affairs.

McDaniel, O. (1996). The theoretical and practical use of performance indicators. Higher Education Management, 8(3), 125-139.

McInnis, C., Griffin, P., James, R. H., \& Coates, H. B. (2001). Development of the Course Experience Questionnaire. Canberra: Department of Employment, Training and Youth Affairs.

Nelson, B. (2003). Our Universities: Backing Australia's future. Canberra: Department of Education, Science and Training.

Nuttall, D.L. (1994). Choosing indicators. In; K.A. Riley \& D.L. Nuttall (Eds.) Measuring Quality: Education Indicators: United Kingdom and international perspectives. London: The Falmer Press.

Ramsden, P. (1991). A performance indicator of teaching quality in higher education: The Course Experience Questionnaire. Studies in Higher Education, 16(2), 129-150.

Times Higher Education Supplement (THES) (2004). World University Rankings. London: Times Higher Education Supplement.

Usher, A., \& Savino, M. (2006). A World of Difference: A Global survey of university league tables. Toronto: Educational Policy Institute.

Williams, R. \& Van Dyke, N. (2005). Melbourne Institute Index of the International Standard of Australian Universities, 2005. Melbourne: University of Melbourne, Melbourne Institute of Applied Economic and Social Research. 


\section{University Library}

\section{- M M I N E R VA A gateway to Melbourne's research publications}

Minerva Access is the Institutional Repository of The University of Melbourne

Author/s:

COATES, HAMISH

Title:

Excellent measures precede measures of excellence

Date:

2006

Citation:

Coates, H. (2006). Excellent measures precede measures of excellence. In Proceedings of the AUQF 2006: Quality outcomes and diversity, Perth, Australia.

Publication Status:

Published

Persistent Link:

http://hdl.handle.net/11343/28876 